であるが，資金上の理由などにより高度な熱回収を行ってい る施設はほとんどない。塩化水素などによる腐食環境などが 都市ごみの場合と比べ厳しい条件となることが多いため，高 度な熱回収設備への政策的な誘導，費用対効果に優れた耐腐 食技術や選別システムの開発などが今後の課題である。

\section{文 献：References}

$\begin{array}{lll}\text { 1) http://www.env.go.jp/recycle/waste/tool_gwd3r } & \text { 2) http:// }\end{array}$ www.env.go.jp/recycle/circul/keikaku.html 3 3)環境省大臣宫房廃宩物 · リサイクル対策部廃亲物対策課，日本の廃亲物処理 平成 17 年度版 4) 環境省編，環境・循環型社会白書 平成 19 年度版

\title{
4. エンジンの動向
}

\section{1 陸用エンジン}

\section{1. 国内市場における陸用エンジンの推移}

近年のエネルギー環境問題を社会事情として，陸用エンジ ン分野における，ガスエンジン普及は益々増加している。世 界の一次エネルギー需要は, 経済成長に伴い増加する。国際 エネルギー機関 (IEA) の見通しでは, 2000 年 91 億石油換算 トンが 2030 年には 153 億石油換算トンに達すると予測されて いる。エネルギー種では, 天然ガスが他のエネルギーに比し て伸び率が最大と予測 ${ }^{1}$ されている。2030年の部門別エネル ギ一源を見ると(図 1 参照), 交通輸送部門では石油依存度が 高いが, 発電部門では石油が 4 \% 程度に減少し, 一方天然力゙ スが $31 \%$ に達すると見込まれている1)。国の長期エネルギー 需給見通し（2001 年 7 月）では，一次エネルギー供給量に占 める天然ガスの比率は 1990 年度 $10.1 \%, 1999$ 年度 $12.7 \%$ か

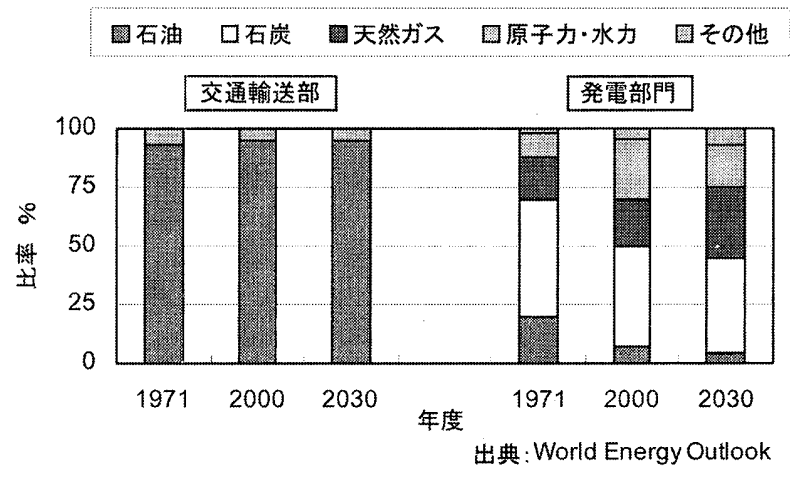

図 1 部門別エネルギー源予測11

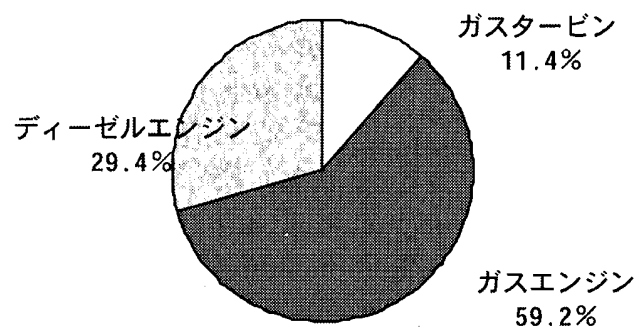

民生・産業用設置件数割合

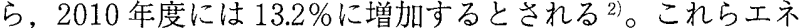
ルギー事情の变化は，原油価格高騰や不安定な供給に対する 対策，および地球温暖化等の環境対策に依る。天然ガスから 発生する $\mathrm{CO}_{2}$ は, 石炭の約 6 割, 石油の 7 割程度と, 化石燃 料の中で最も低いことから，天然ガスの利用が環境負荷軽減 の具体策の一つとなる。従い，陸用発電分野では，排出ガス 中の環境影響物質量が少ないガスエンジンが，定置型原動機 の主流となっている。

図 2 は年間原動機別発電容量の推移を示す ${ }^{3)}$ 。ガスエンジン は着実な延びを示すが，ディーゼルエンジンは増減が激しい。 ディーゼル用の液体燃料（主として重油）価格変動が影響し ていると考えられる。最近は，既設陸用ディーゼルエンジン のガス化改造の検討がされている。

国内コージェネレーション用原動機の 2007 年 3 月末までの 設置件数抒よび設置台数の累計 ${ }^{3)}$ によると，ガスエンジンの 設置件数は $59 \%$ ，台数は $52 \%$ と過半数を越えた (図 3 参照)。

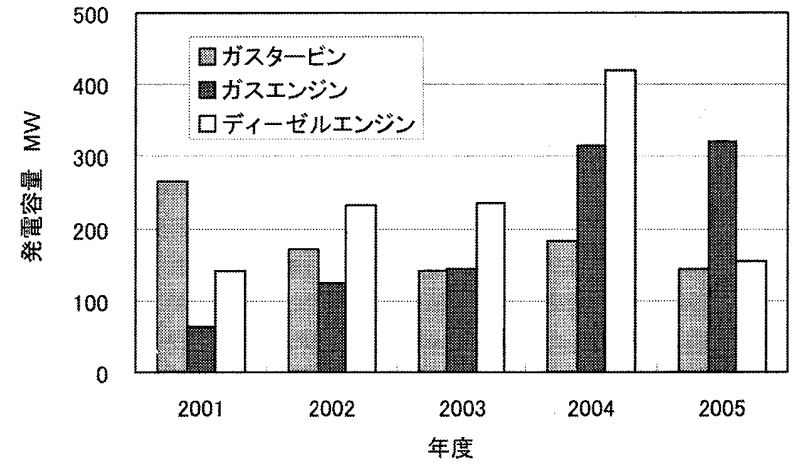

図 2 年度別原動機発電容量の推移 3 )

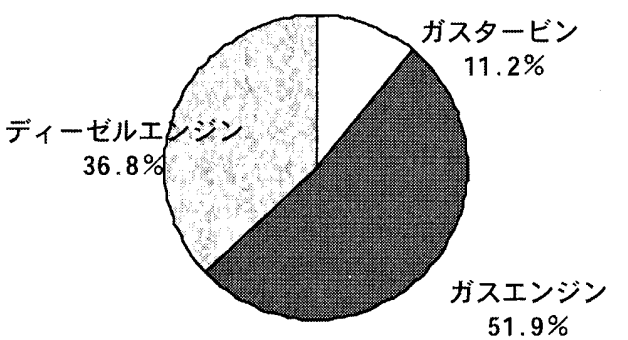

民生・産業用設置台数割合

図 3 各種原動機設置件数および設置台数比較 ${ }^{3}$ 
表 1 原動機種別発電容量（台数当り kW） ${ }^{3}$ )

\begin{tabular}{c|c|c|c}
\hline & $\mathrm{GT}$ & $\mathrm{GE}$ & $\mathrm{DE}$ \\
\hline 民生用 & 762 & 132 & 336 \\
\hline 産業用 & 4,297 & 1,200 & 1,052 \\
\hline
\end{tabular}

GT:ガスタービン, GE:ガスエンジン, $\mathrm{DE}:$ ディーゼルエンジン

原動機種別発電容量は表 1 に示される。

\section{2. 都市ガスコージェレレーションの動向}

コージェネレーションシステムは, 熱電併給により総合エ ネルギー効率が70～ $80 \%$ と省エネルギー性，経済性，環境保 全性に優れている。都市ガスを燃料としてエンジンで発電し， この時に生じる排熱を蒸気や温水に変えて利用するコージェ ネレーションは, 工場の生産工程，ホテルや病院の給湯や蒸 気供給, ビルの冷暖房, 温水プールの加温などに有効利用さ れる。現在普及している最新型コージェネレーション用ガス エンジンの発電効率は 40\%を越光，その他 30 ～40\%は蒸気 または温水として回収利用されている。

$5 \sim 20 \mathrm{~kW}$ の小型ガスエンジンは，ユニット化され民生用 の給湯需要が多い市場に導入されている。1 MW〜 $6 \mathrm{MW} の$ 中大型ガスエンジンは, 発電端 $40 \%$ 以上の高効率化開発に従 い，熱需要の少ない市場に導入されている。 $5 \mathrm{MW}$ クラスを 越える大型コージェネレーションは，ガスタービンが殆どで あったが，最近は高効率ガスエンジンがこの分野に普及して きている。国内外のエンジンメーカーが，5 MW 超の大型ガ スエンジン開発に取り組んでいる。

一方, 電力自由化の進展によりエネルギーサービス事業, い わゆるESCO 事業が活発である。これらは，発電のみのプラ ントであり，熱エネルギーは利用されない。従い，電気料金 の低減とかエネルギー利用形態の景気変動にともなう変化な ど，長期間の事業として検討した場合の不透明さがあるため， 一層の経済的運用計画の根底となる高発電効率および高総合 効率のシステムが要求されている。

\section{3. 再生可能エネルギー有効利用}

天然ガス以外の気体燃料の有効利用が検討される。最近の 動向としては，都市ゴミ熱分解ガスや木質バイオ熱分解ガス がある。熱分解により生成されたガスは，ガス変換方式およ び廃棄物の種類・性状，並びにプラント運転条件の違いによ り，その組成や発熱量が異なる。代表的な例としては，水素， 一酸化炭素抒よび二酸化炭素を各々 30〜35\%含み，真発熱量 は約 7.5MJ/ $\mathrm{Nm}^{3}$ と都市ガス $13 \mathrm{~A}$ の概ね 1/6 である。

一方，この種のガス発電では，然料ガス発生量が変動する ことが実用上の課題である。発生量・熱量が季節，時間変動 するバイオガスと, 安定している都市ガス (13A ガス) とを 混合・燃焼（混焼）させ，コージェネレーションの連続運転 を可能にする混焼システムが実用化されている

最近，国内では木屑ガス発電としては $2500 \mathrm{~kW}$ と最大級の 発電事業が開始されている5。

このように，熱分解ガス有効利用，再生可能エネルギーが,
化石燃料の代替や地球温暖化防止の観点からも注目されてい る。

\section{文 献：References}

1)World Energy Outlook 2002 2) 日本ガス協会, http://www.gas.or.jp/ defaulthtml 3) CGC NEWS, 23(9)，(2007） 4) 日本ガス協会, http:// www.gas.or.jp/default.html $\quad 5 ）$ 北陸中日新聞など，2008 年 5 月 13 日

\section{2 舶用エンジン}

平成19年12月の (社) 日本舶用工業会の年次統計によると, 平成 18 年に竣工した $2,000 \mathrm{DWT}$ 以上の商船に搭載された推進 用ディーゼルエンジンは 1,917 台，22,398MW（対前年比 125 \%)である。機関製造国別で見ると，第 1 位は韓国で10,562MW (シェア 47\%)，日本は第 2 位で5,903MW（シェア 26\%)，続 いて中国が第 3 位で1,864MW（シェア $8 \%$ ) となっており，以 下，ドイッ，ポーランドの順となっている。韓国の増加が大 きく，前年比 $137 \%$ 生産量であった。

2 ストロークエンジンの生産実績は $18,986 \mathrm{MW}$ (対前年比 $123 \%)$ ，また 4 ストロークエンジンの生産実績は $3,412 \mathrm{MW}$ （対前年比 137\%）であった。このうち，2 ストロークエンジ ンについてはMAN型が $15,213 \mathrm{MW}$ (シェア $80 \%$ ) で，第 2 位 のWartsila型が3,039MW（シェア16\%），三菱UE型がこれに 続いて 734MW（シェア 4 \%) であった。また，4 ストローク エンジンについては，第 1 位の Wartsila 型が 885MW（シェア $26 \%$ ）で，第 2 位の MAN 型が $851 \mathrm{MW（シェア} 25 \%$ ），第 3 位の MAK 型が 798MW（シェア 23\%）であった。

製品技術面では将来の環境規制の強化を踏まえて，電子油 圧制御型エンジンを搭載する船舶が増加傾向にあり，平成19 年 12 月末現在で 1,000 台超の 2 ストローク電子油圧制御型工 ンジンの受注数量が報告されている。また，環境対応技術 （SCR，EGR，水噴射よる NOx 低減法など）の開発も活発に行 われており，特に日本においては(独)海上技術安全研究所を 中心にエンジンメーカー数社が参画した「船舶からの環境負 荷低減のための燃焼改善技術及びSCR触媒等に関する調査研 究」が開始された。

環境関連では，海洋污染防止条約 (MARPOL73/78) の付属 書りの「船舶からの大気污染防止のための規則」が既に平成 17 年 5 月に発効し, 総トン数 400 トン以上の全船舶に搭載さ れる出力 $130 \mathrm{~kW}$ を超えるディーゼルエンジンに窒素酸化物 (NOx) の排出制限が実施されている。この規則の見直しが 2 年前から行われており，平成19年も4月に開催されたIMO(国 際海事機構) のBLG11 (海洋環境保護委員会の小委員会), 及 び11月に開催されたBLG-WGAP2（大気污染作業部会第 2 回 中間会合）の 2 回にわたり次期規制の検討が行われた。

中間会合では，新造船のディーゼルエンジンに対する強化 （2 次規制及び 3 次規制）が検討され，2 次規制は平成 23 年 から実施することとされ，現行規制值から $2 \sim 3.5 \mathrm{~g} / \mathrm{kWh}$ 削 